\title{
Waarom belt u mij eigenlijk; ik bel u toch ook niet?
}

\section{Een onderzoek naar corporate engagement vanuit}

\section{klantenperspectief}

Henk Roest en Léon Savelkoul

SAMENVATTING Betrokkenheid is een centraal thema binnen de marketingliteratuur. De theorievorming omtrent betrokkenheid heeft zich echter vooral geconcentreerd op de betrokkenheid vanuit de klant. Veel weten we inmiddels over "customer involvement". De laatste jaren verschuift de aandacht echter naar "customer engagement" waarin de betrokkenheid van de klant met het product of merk verder gaat dan enkel het eigenbelang, en klanten gemotiveerd blijken om tijd en geld te investeren in bijvoorbeeld referentiegedrag, blogging en hulp bij productverbetering. In een poging tot meer klantenbinding claimen steeds meer (dienstverlenende) organisaties dat ze onderscheidend zijn omdat juist bij hen "de klant centraal staat; er écht toe doet; en de organisatie werkelijk betrokken is met de cliënt". Hierdoor ontstaat er behoefte aan meer kennis over betrokkenheid vanuit de organisatiekant en dan vooral wat de klant daarvan merkt. In deze studie introduceren we het begrip "corporate engagement" en onderzoeken de invloed hiervan op klantloyaliteit.

\section{RELEVANTIE VOOR DE PRAKTIJK Dit onderzoek laat zien dat corporate engage-} ment een groot effect heeft op klantloyaliteit en drie conceptuele dimensies omvat: (1) de getoonde interesse in de klant; (2) de mate waarin de relatie wederkerig ervaren wordt; en (3) het enthousiasme dat de organisatie daarbinnen laat zien. De gerapporteerde bevindingen en de gebruikte items die de dimensies representeren kunnen richting geven aan verdere toepassing in de praktijk.

\section{Inleiding}

Een van de ultieme doelstellingen van de meeste organisaties in het algemeen en die van marketing managers in het bijzonder, is het creëren van een langdurige relatie met haar klanten. We zien dit terug in mission statements en marketingstrategieën die doorspekt zijn met mooie intenties die erop neerkomen dat de klant centraal staat en steeds het uitgangspunt is bij alle ac- tiviteiten binnen de organisatie (Treacy \& Wiersema, 1993; Ulaga \& Chacour, 2001; Rogers, 2005; Bügel, Verhoef \& Buunk, 2011). Zo etaleert Rabobank zichzelf graag met de merkwaarde: "wij zijn betrokken," richt Vitalis WoonZorg zich op de klantwaarde dat cliënten werkelijk: "ertoe doen" en adverteert Capgemini Consultancy haar kernwaarde "people matter, results count".

Gegeven het grote belang dat organisaties er blijkbaar aan hechten zou men kunnen verwachten dat ook de theorieontwikkeling over betrokkenheid vergevorderd is. Dit blijkt slechts ten dele het geval. Weliswaar is er veel onderzoek gedaan naar betrokkenheid, maar het leeuwendeel hiervan is gericht op de betrokkenheid van klanten met producten/merken op transactieniveau (customer involvement; zie paragraaf 2.1) danwel op de betrokkenheid van klanten met een organisatie/ merk op relatieniveau (customer engagement; zie paragraaf 2.2). Relatief weinig weten we nog over de betrokkenheid van organisaties met haar klanten. Dit is vreemd omdat vooral dienstverlenende organisaties graag juist dít aspect centraal stellen in hun marketingcommunicatie en zichzelf juist híermee willen onderscheiden en profileren ten opzichte van de concurrentie. Dit type betrokkenheid kunnen we aanduiden met het begrip corporate engagement.

In dit artikel gaan we in op de conceptualisatie van corporate engagement en onderzoeken we in welke mate percepties van corporate engagement effect hebben op klantloyaliteit. Het begrip corporate engagement is nieuw in de literatuur en daarom wordt dit begrip aangesneden via de bestaande conceptualisaties van respectievelijk customer involvement en customer engagement. Daarna wordt verslag gedaan van een studie waarin gezocht wordt naar de dimensies waaruit corporate engagement is opgebouwd. Vervolgens wordt gekeken naar het effect van deze dimensies op klant- 
loyaliteit. Ten slotte worden enkele aanbevelingen gedaan voor managers en worden beperkingen van deze studie besproken.

\section{Theoretische achtergrond}

Sinds een paar jaar wordt er in de marketingliteratuur aandacht besteed aan het begrip engagement. Engagement als nieuw concept lijkt te passen in de zoektocht naar mogelijkheden om de relatie met klanten op te bouwen en te verstevigen. Gerelateerde begrippen betreffen ondermeer "klantparticipatie" (Brodie et al., 2013; Yim et al., 2012), 'co-creatie" (Prahalad \& Ramaswamy, 2004), "brand attachment en brand commitment" (Park et al., 2010; Warrington \& Shim, 2000), en vooral "customer involvement” (Laurent \& Kapferer, 1985; Celsi \& Olson, 1988; Laaksonen, 1994; Park \& Moon, 2003). Voor een beknopt overzicht van de verschillen tussen deze en andere concepten wordt verwezen naar Vivek (2009) en Hollebeek (2013). Omdat involvement het meest verwant is aan engagement wordt eerst dit concept beschreven. Dit biedt een goede basis om vervolgens de stap te maken naar customer engagement en daarna corporate engagement verder te specificeren.

\subsection{Customer involvement}

Consumenten hebben soms meer belangstelling in of voelen zich meer verwant met bepaalde producten en merken dan met andere. Dit uit zich bijvoorbeeld in de invloed die customer involvement heeft op de mate van aandacht voor bijvoorbeeld een advertentie (Celsi $\&$ Olson, 1988), de mate waarin we informatie kunnen en willen verwerven en verwerken (Petty, Cacioppo \& Schumann, 1983; Park \& Moon, 2003), welke producten en merken we prefereren boven andere, en ook op de bereidheid om meer voor dat merk te betalen (Belk, 1982). Met andere woorden: de effectiviteit van de inzet van marktinstrumenten wordt sterk beïnvloed door de mate van involvement van de consument. Om die effectiviteit te vergroten is er veel onderzoek gedaan naar zowel de theoretische aspecten van customer involvement (wat is het en hoe meet ik het?) als naar de praktische aspecten ervan (hoe werkt het en hoe kan ik het managen?).

Ondanks dat er in de loop van de jaren verschillende definities zijn ontwikkeld, bestaat er inmiddels consensus over het idee dat customer involvement een emotionele gemoedstoestand omvat die het resultaat is van een subjectieve waarneming dat een product, activiteit of situatie voor de consument persoonlijk relevant of interessant is. Het geeft richting aan cognitieve processen en veroorzaakt motivationele reacties. Consumenten die een product, activiteit of situatie relevant voor zichzelf beschouwen - in de zin dat deze instrumenteel geacht worden om de persoonlijke waarden en doelen te verwezenlijken - worden "involved" genoemd. Invol- vement wordt door de consument ervaren als belang en belangrijk, waarmee tevens gevoelens en algemene opwinding gepaard gaan (Peter \& Olson, 2008). Ondanks dat sommige mensen voortdurend betrokken zijn met bepaalde producten, merken en activiteiten, doen dergelijke gevoelens van betrokkenheid zich meestal voor op bepaalde momenten en in specifieke situaties, bijvoorbeeld pas als een horloge stuk is en een nieuwe moet worden aangeschaft.

Mittal en Lee (1989) onderscheiden drie dimensies die samen customer involvement omvatten: (1) signaalwaarde, gericht op het bereiken van sociale doelen en zogenaamd impressiemanagement; (2) hedonische waarde, gericht op het ervaren van plezier en genot; en (3a) utiliteitswaarde, het functioneel profijt voorkomend uit de keuze voor de productcategorie of (3b) risicowaarde, de vrees om een verkeerde keuze te maken binnen de productcategorie. Ook Jensen, Carlson en Tripp (1989) vinden bewijs voor de multi-dimensionaliteit van customer involvement en onderkennen naast sociaal psychologische aspecten (zoals de gevoelde druk van mensen uit je directe omgeving om een bepaalde type product of merk te kopen) ook persoonspecifieke aspecten van involvement (zoals je persoonlijke preferentie voor en commitment naar een specifiek merk).

In de literatuur zijn op basis van beschreven customer involvement dimensies inmiddels diverse meetschalen ontwikkeld voor het meten van voortdurende involvement, situationale involvement, product-involvement, aankoop-involvement, et cetera (zie bijvoorbeeld de AMA Marketing Scales Handboeken).

Peter en Olson (2008) hebben een model ontwikkeld met antecedenten van product-involvement bij consumenten. Deze veroorzakers van persoonlijke relevantie en daarmee customer involvement, kunnen worden gerubriceerd in drie clusters.

1. Consumenten-kenmerken betreffen ondermeer het zelfbeeld, specifieke consumentenbehoeften en doelen, de expertise van de consument en persoonlijkheidskenmerken. Alhoewel relevant voor de mate van involvement van de klant, zullen managers deze consumentenkenmerken echter veelal niet zelfstandig kunnen beïnvloeden. Wel kan men er uiteraard rekening mee houden bij het uitzetten en uitvoeren van marketingbeleid door bijvoorbeeld te communiceren in termen van concrete productattributen met ervaren productgebruikers, en in termen van gebruiksconsequenties en voordelen wanneer men in contact wil komen met minder ervaren consumenten (Walker et al., 1987).

2. Productkenmerken handelen over bijvoorbeeld de (relatieve) prijs van het product, de symbolische betekenissen, en mogelijk slechte prestaties en eventueel letsel bij gebruik. In tegenstelling tot de consumentenkenmerken zijn deze productkenmerken juist heel goed te beïnvloeden door managers en kan 
men hiermee consumenten-involvement nauwgezet sturen. Een hoge prijs leidt vrijwel altijd tot een hogere betrokkenheid en ook als er grote kwaliteitsverschillen zitten in het productaanbod, zal de involvement van de klant groter worden.

3. Situationele context-kenmerken tenslotte betreffen onder andere de koopsituatie, eventuele tijdsdruk, de fysieke omgeving en het beoogd gebruik van het product (o.a. Quester \& Smart, 1998). Ook bij deze kenmerken doen zich legio mogelijkheden voor om de involvement van consumenten te vergroten en daarmee de motivatie te verhogen om langer te zoeken naar het desbetreffende product of merk, meer informatie te willen en kunnen verwerken, of om er meer voor te willen betalen.

\subsection{Engagement}

Terwijl betrokkenheid in de betekenis van involvement al sinds de jaren tachtig onderwerp van aandacht is in zowel de marketingtheorie als in de marketingpraktijk, is de interesse omtrent betrokkenheid in de betekenis van engagement pas onlangs gewekt in de marketingliteratuur. Anders dus dan bij involvement is de conceptualisatie van het begrip en hoe dit vervolgens te meten en te managen nog volop in ontwikkeling. Belangrijke fundamenten kunnen daarbij echter worden gevonden in ondermeer de psychologie en de (arbeids)sociologie. Schaufeli et al. (2002), bijvoorbeeld, ontdekten dat engagement in een werk-studiesituatie diverse facetten omvat zoals volharding (hoge mate van energie en grote mentale veerkracht), toewijding (het gevoel ertoe te doen, enthousiasme, inspiratie, trots en uitdaging) en absorptie (volledig geconcentreerd zijn, ergens in opgaan). May et al. (2004) vonden dat "het gevoel betekenisvol te zijn" - zich ondermeer uitend in verticale taakverrijking en de passendheid van de taakomschrijving - het sterkst de mate van employee-engagement bepaalt. Daarnaast bleken ook veiligheid en de toegang tot benodigde bronnen en middelen deze vorm van betrokkenheid bij werknemers significant te beïnvloeden.

Hieronder maken we de stap naar engagement in een marketingcontext en concentreren we ons eerst op de customer engagement-literatuur en vervolgens op corporate engagement.

\section{Customer engagement}

Kijkend naar de beschikbare engagementliteratuur in een commerciële omgeving, dan zien we de laatste jaren vooral een grote kennisontwikkeling rondom customer engagement, in het bijzonder nadat het Marketing Science Institute dit concept omarmde als onderzoeksprioriteit (MSI, 2010). Recent onderzoek laat zien dat customer engagement een positief effect heeft op ondermeer: vertrouwen (Hollebeek, 2011), cross-selling en share-of-wallet (Flynn, 2012), tevredenheid (Bowden, 2009), klantwaarde (Schau et al., 2009), en loyaliteit (Bowden, 2009).

Hoewel er nog geen algemeen geaccepteerde definitie van customer engagement voorhanden is, lijkt de omschrijving van Wagner en Majchrzak (2007) wel de kern ervan te benaderen. $\mathrm{Zij}$ omschrijven customer engagement als: de intensiteit waarmee klanten participeren met de organisatie en andere klanten in een gemeenschappelijk kennisuitwisselingsproces. Patterson, Yu en De Ruyter (2006) en Hollebeek (2011) zien deze participatie als een mix van cognitieve (denken), affectieve (voelen) en conatieve (handelingen) investeringen van een klant in specifieke interacties rondom een organisatie of een merk en die de verbondenheid daarmee aangeven (Mollen \& Wilson, 2010). Allen onderstrepen het belang om verder te kijken dan zowel 'het koopgedrag' als 'het eigenbelang' van de klant, en vooral de wederzijdse constructieve relatie tussen de klant en de aanbieder (de organisatie of het merk) te bestuderen. Deze relatie gaat verder dan de transactie - het kopen, danwel het besluit om niet te kopen - en omvat ook activiteiten die niet direct gerelateerd zijn aan de verwerving van een product. Daarbij kunnen we denken aan activiteiten zoals participatie en co-creatie door de klant, referentiegedrag, het opzetten van brand communities, en het deelnemen aan online chat forums die product- en merkissues bespreken (Van Doorn et al., 2010).

De basis van deze activiteiten wordt door Vivek (2009) gevonden in de vijf consumptie-waarden van Sheth, Newman en Gross (1991). Functionele waarde komt daarbij voort uit hoe goed een product presteert of functioneel is, zoals de extra ruimte die een nieuw koophuis biedt ten opzichte van het oude gehuurde studentenappartementje. Sociale waarde wordt ontleend aan een zekere associatie met en rechtvaardiging binnen sociale groepen, zoals de wetenschap dat goede studievrienden een vergelijkbare woning bezitten. Emotionele waarde betreft het affect dat wordt opgewekt door aanschaf van het product of de consumptie ervan, zoals het gevoel meer (financiële) zekerheid te hebben met het bezit van een eigen huis. Epistemische waarde vindt haar basis in het feit dat iets nieuw is en in ontwikkeling, zoals het plezier dat mensen vinden om in een nieuwe omgeving te mogen wonen en een nieuw huis te mogen inrichten. Conditionele waarde, ten slotte, appelleert aan de specifieke consumptiesituatie waarin de consument terecht komt en de mogelijkheden die dat biedt, zoals het perspectief om nu een gezin te kunnen stichten.

Gebruikmakend van diverse kwalitatieve en kwantitatieve methoden komt Vivek (2009) uiteindelijk tot de volgende dimensies van customer engagement:

1. bewustzijn; het bewustzijn en kennis hebben van het engagement-object ("Het is zoals bij een goede of een slechte film die je ziet. Bij een goede film zit je op het punt- 
je van je stoel, terwijl als het een slechte film is, dan zie je slechts plaatjes passeren");

2. enthousiasme; opgewonden zijn over en positieve bezieling hebben met het engagement-object ("Het is belonend. Als je een hele tijd bezig bent geweest met een werktaak ... en het is dan eindelijk echt klaar, daar krijg je een kick van");

3. sociale interactiviteit; de uitwisseling van gedachten, ideeën en gevoelens met anderen ("Je kunt samen met andere rustig praten, zoals wij nu samen doen. Het creëert een familiale sfeer en dat grijpt me");

4. activiteit; de fysieke activiteit en het bezig zijn met het engagement-object ("Ik was erg begaan met dit project. Ik hield het steeds in de gaten en ging steeds terug op de website om te ontdekken op welk project het meest werd gestemd. Ik heb ook zelf mijn eigen opzet aangeboden om mijn bijdrage te leveren"); en

5. innovativiteit; het gevoel en de ervaring aan het front te staan en nieuwe dingen te ontdekken ("Het geeft een zekere voldoening om met dit soort zaken op deze manier om te kunnen en mogen gaan. Dat werkt verfrissend").

Vivek, Beatty en Morgen (2012) constateren vervolgens dat innovativiteit en enthousiasme vaak samen blijken te gaan (passie) en ook bewustzijn en activiteit meestal in combinatie voorkomen (absorptie).

Anders dan bij customer involvement draait het bij customer engagement dus om een sociale, interactieve binding met het engagement-object waarin de consument helemaal op kan gaan. Engagement onderkent naast het belang van een zekere instrumentele waarde (de knikkers), vooral de essentie van de belevingswaarde (het spel) waarbij informatie en andere interessante zaken worden uitgewisseld met anderen in co-creatieprocessen.

\section{Corporate engagement}

Eerder hebben we aangegeven dat steeds meer organisaties hun eigen betrokkenheid met klanten als strategisch speerpunt hebben gekozen en inzetten als wapen om een relatie met haar clientèle op te bouwen. De mate waarin een klant beleeft dat deze erbij hoort/ertoe doet, zal daarbij sterk afhangen van de getoonde betrokkenheid vanuit de aanbieder. Een aanbieder die haar klanten niet enkel beschouwt als "een zak met knikkers" maar inzet op een interactieve open verstandhouding met haar doelgroep, waarbij ook welgemeende aandacht is voor de sociale en hedonische belevingsaspecten en de transactie eerder een logisch gevolg is dan het allesbepalende doel vooraf. Deze vorm van betrokkenheid kunnen we corporate engagement noemen en impliceert het besef dat het gezamenlijke langetermijn- en wederzijdse belang interessanter is dan het kortetermijneigenbelang, de relatie met de afnemer veel verder gaat dan enkel de verkoop van het product, en dat de klant samen met de aanbieder het merk kan en wil ontwikkelen.
In lijn met de equity theorie lijken corporate engagement en customer engagement met elkaar verbonden te zijn; de input versus de output van de klant moet tot op zekere hoogte in balans zijn met de input versus de output van de organisatie (Huppertz et al., 1978). Betrokkenheid van de klant met de organisatie/ het merk lijkt daarmee conditioneel aan de betrokkenheid van de organisatie/het merk met de klant. Band en Guaspari (2003, p. 35) stellen daarbij dat: "A customer engaged organization doesn't only deliver superior results but is also able to adapt and respond more nimbly in a competitive environment".

Kijken we naar de aandacht voor engagement vanuit de organisatiekant in de huidige literatuur, dan constateren we dat deze zich vooralsnog beperkt tot het faciliteren van betrokkenheid bij de klant, bijvoorbeeld door het ook zelf deelnemen in veelal door klanten opgezette engagement platforms (Ramaswamy, 2009). Anderen hebben met name gekeken naar het eventueel ondersteunen en faciliteren bij diverse subprocessen van customer engagement zoals: "learning, sharing, advocating, socializing and co-development" (Brodie et al., 2013, p. 110).

Het toenemend belang van interactieve relatie-ontwikkeling tussen organisatie en klant, het feit dat klanten nieuwe kanalen gebruiken die verder gaan dan het traditionele communicatie- en verkoopkanaal, en organisaties die klanten aan zich willen binden door hen meer centraal te stellen dan de transactie, rechtvaardigt meer onderzoek naar corporate engagement. Om dit onderzoek meer richting te geven is een scherpe definiëring van dit nieuwe construct essentieel en dit is dan ook een van de intenties van deze studie (zie daarvoor paragraaf 5).

In de volgende paragrafen wordt een studie beschreven waarin de dimensionele structuur van corporate engagement wordt onderzocht alsmede de impact die deze dimensies hebben op de klantloyaliteit bij een grote woon-zorgorganisatie in Nederland. Daarmee wordt aangetoond dat als een organisatie zich geëngageerd toont naar haar klanten en laat ervaren dat ze "er werkelijk toe doen", zij eerder een langetermijnrelatie willen aangaan met de desbetreffende organisatie.

\section{Onderzoeksopzet}

Er is voor gekozen om een vragenlijst uit te zetten onder 510 cliënten van een woon-zorgorganisatie waarin middels een 5-punt Likertschaal gevraagd wordt naar een evaluatie op 30 items die mogelijk iets kunnen zeggen over corporate engagement en drie items die klantloyaliteit moeten vaststellen. De gebruikte corporate engagement-items zijn ondermeer gebaseerd op de customer engagement-dimensies van Vivek (2009), maar dan vertaald naar klantpercepties van organisatiebe- 
wustzijn, -activiteit, -enthousiasme, -interactiviteit, en -innovativiteit. Enkele voorbeelden hiervan zijn: "XYZ is een organisatie die klanten betrekt bij ontwikkelingen in de organisatie" (interactiviteit), "XYZ geeft me het gevoel dat ik word gewaardeerd" (bewustzijn), en "XYZ schept de ruimte voor het beleven van mooie momenten" (activiteit). Deze set van items is vervolgens voorgelegd aan vijf cliënten, vijf medewerkers en drie externe experts werkzaam binnen de sector. Hun opmerkingen, aanvullingen en overige feedback hebben er toe geleid dat de stellingen waar nodig zijn aangevuld of aangepast (stellingen zijn hierdoor soms net iets beter verwoord). Klantloyaliteit is vastgesteld met drie items die zijn ontleend aan Han, Kwortnik en Wang (2008) en Gremler en Gwinner (2000); "Als ik opnieuw zou moeten kiezen, dan koos ik weer voor XYZ", "Ik beveel XYZ graag aan bij derden" en "Als ik in de toekomst andere diensten nodig heb, dan kies ik weer voor XYZ."

De nettoresponse was 185 (35\%) en representatief op diverse populatiekenmerken zoals leeftijd en geslacht. Tien respondenten zijn uit de dataset verwijderd wegens het grote aantal missing values.

\section{Resultaten}

Om te achterhalen hoe de dimensionale structuur van corporate engagement eruit ziet, is eerst een Principale Componenten Analyse met Varimax-rotatie uitgevoerd op de 30 items. Doordat een hoog percentage van de respondenten een of meerdere stellingen niet had beantwoord (43\%) en dit een probleem vormt voor de analyse, is een Expectation Maximization-procedure uitgevoerd om deze ontbrekende datapunten te schatten.

Uit de Principale Componenten Analyse blijkt dat er volgens het Kaiser-criterium drie componenten met een Eigenwaarde groter dan 1 zijn en er dus blijkbaar drie dimensies van corporate engagement kunnen worden onderkend (zie tabel 1). Zowel de de Bartlett's test (coëfficiënt $=4998.99 ; \mathrm{p}$-value $=.000)$ als de KMOmaatstaf (.945) tonen de geschiktheid van het gebruik van deze vorm van Factor Analyse voor deze dataset aan. Samen verklaren de drie dimensies $67 \%$ van de totale variantie. Deze dimensies kunnen we Interesse (19 items; $a=.97$ ), Wederkerigheid (6 items; $a=.91$ ), en Enthousiasme (5 items $a=.84$ ) noemen. De details van deze drie (intern consistente) factoren zijn weergegeven in tabel 1 . Ook de drie items die loyaliteit moeten meten, vertonen een hoge (inter-item consistente) betrouwbaarheid met een Cronbach's alfa van .96.

Door middel van een regressieanalyse kan vervolgens de impact van de drie benoemde corporate engagementdimensies op klantloyaliteit bepaald worden. Daarvoor worden de scores op de items die binnen dezelfde dimensie vallen gemiddeld. De regressieanalyse laat zien dat interesse $(B=.77, t=6.26, p<.001)$ en enthousiasme $(B=.34, t=3.34, p<.001)$ een significante invloed hebben op klantloyaliteit, $\mathrm{F}(3,178)=89.14, \mathrm{p}<.001, \mathrm{R}^{2}$ adj. $=.60$. Interesse voor de cliënt en oprechte persoonlijke belangstelling in wat deze bezighoudt, blijkt daarmee de meest significante en belangrijkste voorspeller van klantloyaliteit: hoe groter de ervaren interesse van de organisatie voor de klant is, hoe hoger ook de loyaliteit. Daarnaast beïnvloedt ook het enthousiasme dat wordt getoond door de organisatie en gewekt bij de klant door middel van diverse (vaak niet-transactie gerichte) activiteiten, de loyaliteit van klanten; maar in iets mindere mate. Wederkerigheid - waarmee aangegeven wordt dat de organisatie actief vraagt naar en rekening houdt met de mening en inzet van de klant - lijkt in dit onderzoek geen significant effect te hebben op de klantloyaliteit.

\section{Discussie en aanbevelingen}

Organisaties claimen vaak dat ze hun klanten centraal stellen bij al haar activiteiten. Grote nadruk wordt daarbij gelegd op strategieën van customer intimacy en relatiemanagement, waarbinnen met name het topic loyaliteit de afgelopen jaren veel aandacht gekregen heeft binnen de marketingliteratuur (zie Roest $\&$ Hulsen, 2008). Opvallend is echter dat daarbij vooral wordt gekeken naar de mate waarin de klant loyaal, begaan of betrokken is met het desbetreffende merk en/ of de producerende organisatie. Vrij weinig weten we nog over getoonde betrokkenheid door de organisatie zelf in die relatie en wat het effect hiervan is op de loyaliteit van de klant.

In dit onderzoek hebben we allereerst gekeken naar het nieuwe concept engagement en hebben we bestudeerd waarin het verschilt met involvement; een andere vorm van klantbetrokkenheid met een merk - al dan niet in een specifieke situatie - en waar al relatief veel onderzoek naar is verricht. Ons baserend op beschikbare literatuur, constateren we dat involvement zich vooral richt op betrokkenheid als gevolg van het persoonlijk belang met de aanschaf van een product of merk. Engagement daarentegen, is een vorm van betrokkenheid die verder gaat dan de transactie en tevens interactieve activiteiten omvat met andere belangengroepen zonder dat daar per se een instrumenteel eigen voordeel tegenover hoeft te staan. Mensen die "engaged" zijn blijken verder een vorm van passie te hebben met het engagement-object en kunnen daardoor cognitief, affectief en conatief volledig geabsorbeerd worden. Bij klanten uit zich dat ondermeer in het gebrek aan tijdsbesef wanneer ze er mee bezig zijn en het enthousiasme waarmee ze onderling met elkaar communiceren over het product, en hun ervaringen en adviezen uitwisselen.

$\mathrm{Nu}$ we zien dat met name dienstverlenende organisaties steeds vaker claimen dat ze bijzonder betrokken zijn met hun klanten en zelfs veel meer dan hun concurren- 
Tabel 1 Uiteindelijke oplossing Principale Componenten Analyse

\begin{tabular}{|c|c|c|c|c|}
\hline Dimensie & Items & Aantal items & Cronbach's alfa & Factor lading \\
\hline \multirow[t]{19}{*}{ Interesse } & In moeilijke tijden rekenen op XYZ & 19 & .97 & .793 \\
\hline & Persoonlijke aandacht & & & .773 \\
\hline & Echte aandacht geven & & & .751 \\
\hline & Steunen in moeilijke tijden & & & .745 \\
\hline & Dankzij XYZ vertrouwd gevoel hebben & & & .736 \\
\hline & Inbreng van cliënt staat voorop & & & .730 \\
\hline & Gewaardeerd voelen & & & .719 \\
\hline & Gevoel dat ik 'ertoe doe' & & & .691 \\
\hline & Goede relatie onderhouden & & & .687 \\
\hline & Inspelen op wensen en behoeften & & & 677 \\
\hline & Positieve gevoelens oproepen & & & .675 \\
\hline & Vertrouwd voelen in woonomgeving & & & .672 \\
\hline & Ruimte om mezelf te zijn & & & .665 \\
\hline & Rekening houden met wensen & & & .653 \\
\hline & Gastvrij ontvangen & & & .644 \\
\hline & Serieus luisteren & & & .640 \\
\hline & Door medewerkers betrokken voelen bij XYZ & & & .556 \\
\hline & Gevoel geven dat ik mezelf mag zijn & & & .551 \\
\hline & Zorgt dat ik bijblijf op actuele thema's & & & .495 \\
\hline \multirow[t]{6}{*}{ Wederkerigheid } & Goed geïnformeerd worden wat er speelt & 6 & .91 & .766 \\
\hline & Vragen wat belangrijk is voor me & & & .750 \\
\hline & Mogelijkheden bieden om mening te uiten & & & .699 \\
\hline & Betrekken bij ontwikkelingen organisatie & & & .631 \\
\hline & Betrekken bij belangrijke beslissingen zorg & & & 613 \\
\hline & Uitdagen om actief te blijven & & & .502 \\
\hline \multirow[t]{5}{*}{ Enthousiasme } & Kunst- en cultuurprogramma & 5 & .84 & .755 \\
\hline & Geïnspireerd zijn door website & & & .722 \\
\hline & Ruimte scheppen voor mooie momenten & & & 647 \\
\hline & Betrokken voelen door interne media & & & .571 \\
\hline & Door XYZ aangenaam verrast worden & & & .532 \\
\hline \multirow[t]{3}{*}{ Loyaliteit } & Opnieuw kiezen voor XYZ & 3 & .96 & \\
\hline & XYZ aanbevelen bij derden & & & \\
\hline & Kiezen voor andere diensten bij XYZ & & & \\
\hline
\end{tabular}

ten, ontstaat de behoefte om het concept corporate engagement te introduceren. Startend met de kennis die ontwikkeld is vanuit customer engagement hebben we gekeken naar de conceptualisatie hiervan. Net als customer engagement lijkt ook corporate engagement een multi-dimensionaal concept te zijn waarin cognitieve, affectieve en conatieve aspecten een belangrijke rol spelen. Verder lijkt ook bij corporate engagement de focus van de organisatie niet enkel te liggen op het kortetermijneigenbelang (de transactie) maar vooral op het gezamenlijk opbouwen en onderhouden van een op gelijke voet opererende relatie. In die relatie vindt een wisselwerking plaats van ideeën en initiatieven van zowel klanten als de organisatie en zijn beiden begaan met elkaar en via het engagement-object.

Op basis van deze theoretische uitgangspunten is een onderzoek verricht binnen de woon-zorgdienstverle- ning om empirisch vast te stellen uit welke dimensies corporate engagement is opgebouwd en wat het effect is van elk van deze dimensies op de intentie om loyaal te blijven aan de organisatie en dus daarmee een langdurige relatie aan te gaan.

Op grond van de verkregen data hebben we gevonden dat corporate engagement drie dimensies lijkt te omvatten; interesse, wederkerigheid en enthousiasme ${ }^{1}$. Interesse gaat vooral over de belangstelling die de organisatie toont in de klant en als persoon. Wederkerigheid richt zich vooral op het belang dat de organisatie hecht aan de inbreng van de klant en als co-creator. Enthousiasme richt zich op belevingsaspecten zoals de bezieling en de passie die de organisatie zelf uitstraalt en creëert bij de klant.

Daarmee kunnen we corporate engagement definiëren als: de intensiteit waarmee de organisatie interesse en bezieling toont in en gebruik maakt van de gedachten, beleving en bezigheid van haar klanten met het betrokkenheidsobject. 
Vervolgens hebben we onderzocht wat het effect van de drie corporate engagement-dimensies is op klantloyaliteit. De resultaten laten zien dat zowel interesse als enthousiasme een (sterke) impact hebben op de intentie loyaal te blijven, maar wederkerigheid niet. Met andere woorden; naarmate de organisatie (a) laat zien dat er echte interesse is in de klant als individu en deze merkt dat hij/zij wordt gewaardeerd en (b) zelf inspirerend is en dit weet over te dragen naar de klant, klanten zich sterker willen binden aan de betrokken organisatie of het betrokken merk. De reden waarom wederkerigheid geen significant effect heeft op klantloyaliteit is onduidelijk. Wellicht dat de items iets minder goed geformuleerd zijn waardoor het nut van interactie op loyaliteit minder duidelijk blijkt. Ook is het mogelijk dat klanten wederkerigheid als iets "vanzelfsprekend" zien. De gegeven scores op en de spreiding van de desbetreffende items (niet getoond vanwege vertrouwelijkheid) geven in ieder geval nog geen uitsluitsel. Nader onderzoek is dan ook gewenst.

Ook voor marketing managers zijn de gevonden resultaten belangrijk. Zeker binnen dienstverlenende organisaties waarbij de klant nauw aanwezig is bij het dienstverleningsproces, speelt corporate engagement een belangrijke rol. Klanten letten immers sterk op de betrokkenheid waarmee de organisatie haar diensten verleent. Zonder engagement vanuit de organisatie ontstaat er geen (warme) relatie met de klant. We hebben gezien dat klanten vooral waarde hechten aan oprechte belangstelling en gevoelig zijn voor de bevlogenheid die de organisatie toont tijdens het interactieproces met de klant. Gegeven de invloed van zowel de interesse voor de klant als het enthousiasme door de organisatie op klantloyaliteit - welke samen met wederkerigheid corporate engagement omvat - zullen managers meer moeten sturen op die activiteiten die deze veroorzaken. De items die zijn gebruikt tijdens dit onderzoek bieden aanknopingspunten maar zijn uiteraard slechts illustratief voor een nieuw soort betrokkenheid en marketing. Marketing, waarbij we meer en anders moeten luisteren naar onze klanten, meer oprechte interesse tonen in wat klanten beweegt, meer gebruik maken van andersoortige kanalen, de klanten meer empowerment bieden, meer samenwerken en interveniëren, minder voorverpakt moeten communiceren, en minder denken en handelen vanuit de gedachte dat we zelf wel weten wat goed is voor de klant. Klanten lijken tegenwoordig heel goed in staat te zijn om corporate engagement te destilleren uit hetgeen de organisatie presenteert en presteert. De klant merkt direct of ze er werkelijk "toe doen", en anderen trouwens ook via de sociale media. Communiceren dat de bank betrokken en dichtbij is werkt contraproductief als vervolgens kantoren worden gesloten, en ook klanten blijven bestoken met steeds dezelfde tevredenheids- onderzoeken waarin weliswaar naar de opinie van de klant wordt gevraagd maar waar vervolgens niets mee wordt gedaan, toont niet de betrokkenheid waar het werkelijk om gaat. Hoe anders is bijvoorbeeld de werkwijze van de politie die de hulp vraagt en krijgt van het algemeen (televisie)publiek bij de opsporing en preventie van misdrijven en waarbij ook de credits van het geboekte succes worden gedeeld met dit publiek, of zoals bij cross-channel retailer Coolblue die in 2013 gekozen is als meest klantgerichte bedrijf van België ${ }^{2}$ Natuurlijk moeten we voorzichtig zijn met de vertaling van de bevindingen van dit onderzoek naar sectoren buiten de professionele dienstverlening, of die van de woonzorg in het bijzonder. Anderzijds zien we dat ook producenten van fysieke producten reeds werken aan corporate engagement. Uitstekende voorbeelden vinden we ondermeer bij LEGO ${ }^{3}$ en Procter $\&$ Gamble $^{4}$, die bij het (verder) ontwikkelen van producten de hulp vragen van consumenten en deze ook benaderen en behandelen als de échte experts en waarvan je ook iets kan leren als organisatie. Meer onderzoek naar corporate engagement en de betekenis ervan binnen andere sectoren en verschillende producten is aan te bevelen.

Concluderend kunnen we stellen dat corporate engagement door klanten bijzonder wordt gewaardeerd. Het vereist wel dat organisaties zich engageren met de klant en dit met interesse en enthousiasme doen. Onderzoek naar customer engagement toonde reeds aan dat klanten steeds meer bereid zijn en in staat lijken om de relatie naar een volgend niveau te brengen. De liefde moet echter wel van twee kanten komen en niet enkel met de lippen beleden worden. Nog steeds ervaren we bij dienstverleners die weliswaar claimen het beste voor te hebben met hun klanten, een houding van ongeïnteresseerdheid en afstand willen houden. Een initiatief tot meer engagement vanuit de klant eindigt dan ook nog vaak abrupt door een respons van de organisatie in de trant van "Waarom belt u mij eigenlijk; ik bel u toch ook niet?"

Prof. dr. H.C.A. Roest studeerde Bedriffseconomie met als specialisatie Marketing (cum laude) en promoveerde op het terrein van klantverwachtingen en verwachtingenmanagement, beide aan Tilburg University, waar hij momenteel als TiasNimbas hoogleraar Marketing Management werkzaam is bij de School of Economics and Management en de School for Business and Society.

L.G.W. Savelkoul MSc. voltooide de Master of Health Administration aan TiasNimbas Business School en is als directeur Zorg Wonen Welzijn binnen de Vitalis WoonZorg Groep eindverantwoordelijk voor 2 residentiële woonvormen, 2 woon-zorgcomplexen en 1 verpleeghuis gevestigd in Eindhoven en Heerlen. 
Net als bii customer engagement (zie Vivek, 2009) blijkt ook bij corporate engagement de wisselwerking tussen klant en organisatie (interactiviteit of wederkerigheid), een zekere mate van enthousiasme (of mogelijk zelfs passie), en op- rechte interesse in respectievelijk de organisatie (of het merk) en de klant essentieel.

2_Zie: http://www.talktoo.be/blog/coolbluewint-award-voor-meest-klantgerichte-bedrijfvan-belgie.
Zie: http://www.southstreetstrategy.com/ co-creation-lego-friends/.

Zie: http://www.100open.com/casestudies/ pg-consumer-co-creation/.

\section{Literatuur}

- Band, W., \& Guaspari, J. (2003). Creating the customer-engaged organization. Marketing Management, 12(4), 34-39.

- Belk, R.W. (1982). Effects of gift-giving involvement on gift selection strategies. In A. Mitchell (ed.), Advances in Consumer Research, (pp. 408-411). Ann Arbor: Association for Consumer Research.

- Bowden, J.L.H. (2009). The process of customer engagement: A conceptual framework. Journal of Marketing Theory and Practice, 17(1), 63-74.

- Brodie, R.J., llic, A., Juric, B. \& Hollebeek, L. (2013). Consumer engagement in a virtual brand community: An exploratory analysis. Journal of Business Research, 66, 105-114.

- Bügel, M.S., Verhoef, P.C., \& Buunk, A.P. (2011). Customer intimacy and commitment to relationships with firms in five different sectors: Preliminary evidence. Journal of Retailing and Consumer Services, 18(4), 247-258.

- Celsi, R.L., \& Olson, J.C. (1988). The role of involvement in attention and comprehension processes. Journal of Consumer Research, 15(2), 210-224.

- Doorn, J. van, Lemon, K.N., Mittal, V., Nass, S., Pick, D., Pirner, P., \& Verhoef, P.C. (2010). Customer engagement behavior: Theoretical foundations and research directions. Journal of Service Research, 13(3), 253-266.

- Flynn L.M. (2012). An exploration of engagement: A customer perspective. College of Science and Health Theses and Dissertations. Paper 8.

- Gremler, D.D., \& Gwimmer, K.P. (2000). Customer-employee rapport in service relationships. Journal of Service Research, 3(1), 82-104.

- Han, X., Kwortnik jr., R.J., \& Wang, C. (2008). Service loyalty: An integrative model and examination across service contexts, Journal of Service Research, 11(1), 22-42.

- Hollebeek, L. (2011). Demystifying customer brand engagement: Exploring the loyalty nexus. Journal of Marketing Management, 27(7/8), 785-807.

- Huppertz, J.W., Arenson, S.J., \& Evans, R.H. (1978). An application of equity theory to buyerseller exchange situations. Journal of Marketing Research, 15(2), 250-260.

- Jensen, T.D., Carlson, L., \& Tripp C. (1989). The dimensionality of involvement: An empirical test. In T.K. Srull (ed.), Advances in Consumer Research (pp. 680-689). Provo: Association for Consumer Research.

- Laaksonen, P. (1994). Consumer involvement:
Concepts and research. London, Routledge.

- Laurent, G., \& Kapferer, J-N. (1985). Measuring consumer involvement profiles. Journal of Marketing Research, 22(1), 41-53.

- May, D.R., Gilson, R.L., \& Harter, L.M. (2004). The psychological conditions of meaningfulness, safety and availability and the engagement of the human spirit at work. Journal of Occupational and Organizational Psychology, 77(1), 11 37.

- Mittal, B., \& Lee, M-S. (1989). A causal model of consumer involvement. Journal of Economic Psychology, 10(3), 363-389.

- Mollen, A., \& Wilson, H. (2010). Engagement, telepresence and interactivity in online consumer experience: Reconciling scholastic and managerial perspectives. Journal of Business Research, 63, 919-925.

- MSI (2010). 2010-2012 Research Priorities. Boston, Marketing Science Institute.

- Park, C.W., Maclnnis, D.J., Priester, J., Eisingerich, A.B., \& lacobucci, D. (2010). Brand attachment and brand attitude strength: Conceptual and empirical differentiation of two critical brand equity drivers. Journal of Marketing, 74(6), 1-17.

- Park, C.W., \& Moon, B-J. (2003). The relationship between product involvement and product knowledge. Psychology \& Marketing, 20(11), 977-997.

- Patterson, P., Yu, T., \& De Ruyter. K. (2006). Understanding customer engagement in services. Advancing theory, maintaining relevance. Proceedings of ANZMAC 2006 Conference, Brisbane.

- Peter, J.P., \& Olson, J.C. (2008). Consumer behavior \& marketing strategy (8e editie). Homewood, LL: McGraw-Hill.

- Petty, R.E., Cacioppo, J.T., \& Schumann, D. (1983). Central and peripheral routes to advertising effectiveness. Journal of Consumer Research, 10(2), 135-146.

- Prahalad, C.K., \& Ramaswamy, V. (2004). Cocreation experiences: The next practice in value creation. Journal of Interactive Marketing, 18(3), 5-14.

- Quester, P.G., \& Smart, J. (1998). The influence of consumption situation and product involvement over consumers' use of product attribute. Journal of Consumer Marketing, 15(3), 220238.

- Ramaswamy, V. (2009). Leading the transformation to co-creation of value. Leadership, 37(2), 32-37.

- Roest, H., \& Hulsen, M. (2008). Loyale klanten:
Hebben is hebben, maar houden de kunst. In A.E. Bronner et al. (eds). Ontwikkelingen in het Marktonderzoek 2008; Jaarboek Marktonderzoek Associatie, (pp. 129-150). Uitgeverii Spaar en Hout.

- Rogers, M. (2005). Customer strategy: Observations from the trenches. Journal of Marketing, 69(5), 262-263.

- Schau, H.J., Muñez, A.M., \& Arnould, E.J. (2009). How brand community practices create value. Journal of Marketing, 73(5), 30-51.

- Schaufeli, W.B., Martinez, I.M., Pinto, A.M., Salanova, M., \& Bakker, A.B. (2002). Burnout and engagement in university students: A cross-national study. Journal of Cross-Cultural Psychology, 33(5), 464-481.

- Sheth, J.N., Newman, B.I., \& Gross, B.L. (1991). Why we buy what we buy: A theory of consumption values. Journal of Business Research, 22, 159-170.

- Treacy, M., \& Wiersema, F. (1993). Customer intimacy and other value disciplines. Harvard Business Review, 71(1), January-February, 8493.

- Ulaga, W., \& Chacour, S. (2001). Measuring customer-perceived value in business markets: $\mathrm{A}$ prerequisite for marketing strategy development and implementation. Industrial Marketing Management, 30 (6), 525-540.

- Vivek S. (2009). A scale of consumer engagement. Dissertation. Tuscaloosa Alabama.

- Vivek S., Beatty, S., \& Morgen, R. (2012). Customer engagement: Exploring relationships beyond purchase. Journal of Marketing Theory and Practice, 20(2), 122-146.

- Wagner, C., \& Majchrzak, A. (2007). Enabling customer-centricity using Wiki the

- Wiki Way. Journal of Management Information Systems, 23(3), 17-43.

- Walker, B., Celsi, R., \& Olson, J. (1987). Exploring the structural characteristics of consumers' knowledge. In M. Wallendorf en P. Anderson (eds.). NA - Advances in Consumer Research Volume 14, (pp. 17-21). Provo, UT: Association for Consumer Research.

- Warrington, P., \& Shim, S. (2000). An empirical investigation of the relationship between product involvement and brand commitment. Psychology \& Marketing, 17(9), 761-782.

- Yim, C.K., Chan, K.W., \& Lam, S.S.K. (2012). Do customers and employees enjoy service participation? Synergistic effects of self- and other-efficacy. Journal of Marketing, 76(6), 121-140. 